\title{
The Exploration of the Cultural Artistic Features of Folk Embroidery in Lingbao, Henan
}

\author{
Chuncai Zhang \\ Huanghe Science and Technology College \\ Zhengzhou, China
}

\begin{abstract}
Folk embroidery pattern is the visual element of emotion expression and folk art perception accumulation in people's daily life, folk embroidery in Lingbao, Henan patterns can not only express the art of living and practicability, but also reflects strongly decorative arts features of local embroidery. This article shows the traditional culture connotation and the local folk customs through the cultural artistic features of folk embroidery in Lingbao, Henan. It is not only the art of life, but also practical aesthetic art. A variety of embroidery patterns convey a strong cultural connotation and strong emotional factors.
\end{abstract}

\section{Keywords -folk embroidery; artistry; culture; aesthetic arts}

\section{INTRODUCTION}

As common appreciation and wearing in people's daily life, folk embroidery is closely related with people's lives, the embroidery pattern is centered on all things in people's daily life, which are both in a large variety and all-inclusive. Each embroidery pattern contains abundant cultural connotation, showing the local unique folk customs. The pattern, color and content of Henan Lingbao folk embroidery patterns have a distinct and unique artistic features. As a special artistic symbol, it reflects Lingbao local people's habits of appreciation clearly, and permeates customs, feelings western people and carries their unique cultural symbolic meanings.

\section{THE ARTISTRY OF FOLK EMBROIDERY PATTERNS IN LINGBAO, HENAN}

\section{A. The Modeling Symbolism of Folk Embroidery Pattern in Lingbao, Henan}

Symbolic animal, plants and characters constitute the main manifestation of the content of Henan Lingbao folk embroidery pattern. These symbols convey the people's nice expectations towards life through the symbol, meaning, analogy and more homophonic and other means, and constitute a unique form of folk embroidery art symbol system. Among which Henan Lingbao folk embroidery pattern convey people's yearning for beautiful love and a better life pursuit by means of the symbols of Phoenix, mandarin duck and other animal motifs. Another example of Henan Lingbao folk embroidery patterns with the representation by the pattern symbol of Magpies ascending the plum, contains an auspicious meaning and the blessing of their loved ones and longing for a better life. In the form

This paper is a research project of Henan social science research project "Resources protection and development research of Henan folk art" (project number: SKL-2012-1306) it often uses the nature and connotation characteristics of objects to express meanings through objects, such as common modelling of twin flowers, mandarin ducks playing in the water and other forms. Using homophonic and homonym to transmit symbols of auspicious terms is very common, such as the use of Reo Takako, kylin sending a baby to transfer good wishes. In Henan Lingbao folk embroidery patterns, the auspicious symbol is often used to convey people's good wishes, it is common to see that Phoenix playing among peony, carp putting lotus, birds paying homage to the phoenix, the lions rolling silky ball etc. [1] Using material symbols of the representation to reflect the deep cultural connotation, embodies the folk women's thoughts of diligence and wisdom in life and faithfulness in the art, which conveys their simple concepts of life and good psychological desire. In the rich and varied shapes, we can see the clever use and concrete manifestation of symbolic art symbol in the folk embroidery pattern. And the symbols of Henan Lingbao folk embroidery pattern modelling interprets the concept of people's happiness and good luck. It is full of people's lives, linked with people's life closely, however, once the idea evolves into the fact, this fact would become permanent memory of symbols. And the deep cultural connotation behind these symbols has formed a kind of perception mode of Chinese traditional folk culture for thousands of years. How to have an effect on the current people's aesthetic to achieve the fusion of traditional and modern civilization, promote, stimulate people's strong aesthetic resonance thought through the existing folk art resources is the reason of folk art resources protection and inheritance, they not only has realistic aesthetic value, but also has a bearing of the profound meaning of traditional culture.

\section{B. Auspicious, Rich-Modelling Henan Lingbao Folk Embroidery Pattern}

A rich variety of Henan Lingbao folk embroidery patterns is the necessary artistic elements of local people's life activities, and it reflects people's customs, feelings, gradually forms its unique geographical features and artistic style after several generations of inheritance and innovation. In people's life activities and coat dress decorative usage, Henan Lingbao folk embroidery pattern modelling uses plenty of concise and lively shapes as well as colors and a variety of different meaning auspicious patterns to express things rationality, passing out people's good wishes for their loved ones and their longing for life. For example, purse, 
also known as pockets, is not only the most important folk life activities, the articles of festival customs and the love token of young men and women. For different purposes, using different patterns to transfer different auspicious meaning. In the Dragon Boat Festival in May, the local folk is inserted moxa leaf, Yellow Wine drink, and wear sachet to avoid the five poisonous creatures. In order to longevity, people will use the lock, the pattern of tiger as modeling elements in children's purse to drive for safety and use the pattern of peaches offered as a birthday cake to long for longevity. At the same time people will also use the same words to express good wishes, such as "Chinese dragon sending a baby" and "birds paying homage to the phoenix" etc. These embroidery patterns fuse the habits of local people's life and enjoyment, also highlight the local folk customs.

\section{Contrasting, Technicolored Folk Embroidery Pattern in Lingbao, Henan}

Folk embroidery patterns originating from Lingbao, Henan shows a bright clear color system and rich cultural connotations. As important constituent elements of folk art, through the accumulation of thousands of years of natural and cultural environment and concise, color has formed regional characteristics of performance characteristics and cultural connotation in the process of the inheritance and development. The color of folk embroidery patterns, include the ancient art concept, auspicious meaning and cultural connotation, and show a very distinctive aesthetic features in the process of inheritance of the corresponding color system and application rules. The color of Henan Lingbao folk embroidery patterns has not only stresses the existence of the function of appreciation, but a cultural and artistic language of the exchange with the audience, Besides, it embodies deep aesthetic psychological demand of the local people in Lingbao, representing a kind of emotional awareness of the public and is a combination of emotional and cultural implication of the integrated system. Such as embroidery patterns used in marriage and major holiday colors, are in clear bright color, having strong contrast, highlights the auspicious festive holiday atmosphere. Also because of the process, raw materials and other restriction, figure modelling requires concise generalization, this limitation provides favorable conditions for the purity of embroidery pattern colors, the color characteristics but also affected by rules of color vision, traditional culture connotation and the local customs of the folk concept. In some works of insoles and soles of the embroidery, the embroidery techniques of "scarf embroidery" are often used, usually with white color, with black and blue as the application of the patterns in the white color environment, using a knife to cavern out to form a new pattern of the hollow, and then fill in the bright various types of cloth, the embroidery in black and prudent pattern foil bright color patterns, making bright color of the pattern and shows a rich content. Especially the special embroidery art, the bride's wedding dress forms a unique traditional color style affected by specific time, environment and festive atmosphere. With red as dominant hue, using a lot of red in clothes collars, sleeves and skirt, dotted a small area of green and yellow at the same time. The bright red reveals the color of the festive and auspicious, and red and green in sharp contrast to achieve the bright. The sprightly and extremely exaggerated color collocation completely breaks the laws of the natural color, giving their works rich decoration, and forms the artistic features of suiting both refined and popular tastes.

\section{THE CUlture OF FOLK EMBROIDERY PATTERN IN LINGBAO, HENAN}

\section{A. Spreading Love to Show the Cultural Characteristics of Maternal Love}

In the selecting and applying of embroidery pattern, love story is a more prominent performance of the content. Lingbao as the hometown of operas, various folk opera art are deeply loved by local people, and these folk opera art characters, shapes, colors and the stories are also applied to folk embroidery works. For example, "Liang Shanbo and Zhu Yingtai", "picking up the jade bracelet" the artistic content are embroidered carefully and skillfully in the quilt cover, bed, curtain, purse and other life common embroidery. [3] The characters that embroidered have unique shapes, bright colors, pure and simple embroidery image reflects the local people's yearning for the beautiful love and marriage, and placing the girls' happiness of looking forward to love. Some embroidery for children's use of tiger shoes, apron, children's hats and incense bag reflect the mother's love and care to the child, and all the love is contained in every piece of embroidery.

\section{B. The Presentation of Folk Culture Information in Lingbao, Henan}

The local unique folk culture creates a better condition for the inheritance and development of folk embroidery in Lingbao. It also fully embodies the diligence and wisdom of the local women giving the local folkway and custom mystery and beauty. In the process of inheritance and development, the art of Lingbao folk embroidery pattern form shows certain cultural connotation. We can feel the application of Chinese auspicious patterns in Lingbao embroidery everywhere, such as "magpie ascending plum", "Phoenix plays in peony" and other patterns, the cultural content praying auspicious and joy in Chinese traditional culture is clearly visible. When embroidering will, people will inherit traditional embroidery art and shape at the same time, and add some new elements of art according to the different local festivals to show the different cultural content, which mainly takes beautiful love, marriage and children health as the theme to embroider out a variety of practical embroidery and toys. These embroidery has a different cultural connotation and the performance of the content. Such as the Dragon Boat Festival in May is embroidered with a wide variety of incense bag, the content is "Zodiac", the "Eight Immortals", "peach", "moving baby feet" and so on, and the incense bag filled with aromatic spices to expel insect and keep perfume. Children give parents elaborately embroidery to express the good wishes of parents' health and longevity, mother gives it to their children to bless them safe and healthy, the girls takes it as a token of love and gives it to her valentine to express her yearning for a better love and happy mood. Wedding dress of the bride is an exquisite embroidery works of art, there is a ballad as 
evidence: Xiao Jiao Wang becomes a bride, catch embroidered wedding very busy. Lappets finished on the first watch of the night, peony opening in the chest of clothes; coat-tails finished on the second watch of the night, clouds blossoming at the time; surplus finished in midnight, magpie ascending plum to send good news; embroidery flower stalk finished on the fourth watch of the night, conjugal love of husband and wife radiant; just before dawn to end embroidered dragon and Phoenix, affectionate couple fly wing to wing. [4] The embroidered contents and the shape characteristics of bride's wedding gown convey a bride's best wishes for a perfect marriage of vision and expectations cleverly, and expressing local people's ideal of a happy marriage. The layout of bride and groom's bridal chamber is joyous and prosperous using a combination of perfect Mandarin Duck, Phoenix elements and silk to transfer the marriage jubilant and happy. Also at the full moon of a baby, grandma will send tiger head shoes and hats to express her care and love on child praying for safe and healthy. It reflects that embroidery has different connotations in different season

\section{CONCLUSION}

Folk embroidery pattern in Lingbao, Henan fuses art characteristics of practice and decoration, showing the traditional culture connotation and the local folk customs. It is the perfect combination of optimistic attitude towards life and aesthetic ideology of local people. It not only is the art of life, but also aesthetic art of practice. However, folk embroidery pattern is the visual elements to record people's emotional expression in daily life and folk artistic heritage, and it promotes the folk embroidery art extends from the unitary appreciative aptitude to a variety of cultural and artistic embroidery patterns through a variety of embroidery carrier to convey different information content. Besides, it expresses the unique and deep cultural connotation. What the strong cultural connotation behind is strong emotional factors.

\section{REFERENCE}

[1] Li Na: "Chinese traditional pattern and modern decorative art design", Tianjin, Baihua Literature and Art Publishing House, 2011

[2] Zhang Daoyi: "the characteristics of Chinese national art", Beijing, People's Fine Arts Publishing House, 1992

[3] Shang Pingjun: "the analysis of traditional folk art culture", Decoration, 2006

[4] Dai Ping: "Research on Chinese national costume culture ", Shanghai, Shanghai People's Publishing House, 2000. 